${ }^{4}$ Pike JW, Toverud S, Boass A, McCain T, Haussler MR. Circulating $1 \alpha, 25-(\mathrm{OH}){ }_{2} \mathrm{D}$ during physiological states of calcium stress. In: Norman AW, Schaefer K, Coburn JW, et al, eds. Vitamin D. Biochemical, chemical and clinical aspects related to calcium metabolism. Berlin: Walter de Gruyter, 1977: 187-9.

Galan FG, Rogers RM, Girgis SI, et al. Immunochemical characterisation and distribution of calcitonin in the lizard. Acta Endocrinol $1981 ; 97$. 427-32.

(Accepted 30 June 1982)

Endocrine Unit, Royal Postgraduate Medical School, Hammersmith Hospital, London W12 0HS

JOHN C STEVENSON, MB, MRCP, honorary lecturer and senior registrar MICHAEL C WHITE, MB, MRCP, research fellow

GRAHAM F JOPLIN, PHD, FRCP, reader

IAIN MACINTYRE, DSC, FRCP, professor

\section{Death due to overdose of indoramin}

Indoramin (Baratol) is a recently introduced alpha ${ }^{1}$-adrenergic antagonist used to treat essential hypertension. I report a fatal case of self-poisoning with indoramin. This is the first such case to be described.

\section{Case report}

A 43-year-old housewife was admitted to hospital after being found unconscious at home. She had a seven-year history of essential hypertension and was being treated with indoramin and cyclopenthiazide. She was also taking temazepam for night sedation. In 1976 she had been a psychiatric inpatient after taking an overdose of Moduretic and ethanol and selfmutilation of her wrists. One week before admission she had become depressed and was drinking more alcohol than usual. On the day of admission she had prepared the evening meal and then gone to her bedroom; she was found one hour later unconscious. She had taken approximately 100 tablets of $25 \mathrm{mg}$ indoramin.

On admission she was unconscious but responded to pain and was breathing spontaneously. Pulse was 90 beats/min and regular and blood pressure $120 / 60 \mathrm{~mm} \mathrm{Hg}$. The pupils were equal and reacted to light. She was areflexic. Shortly after arrival she had a series of generalised convulsions that were treated with intravenous diazepam. A cuffed endotracheal tube was inserted and gastric lavage carried out. Only a few indoramin tablets were identified in the lavage. Blood pressure fell rapidly to $60 / 0 \mathrm{~mm} \mathrm{Hg}$ and she was given intravenous plasma and the foot of the bed was raised. Further inotropic support was achieved using intravenous dopamine by sage pump. Severe metabolic acidosis ( $\mathrm{pH} 7 \cdot 04$, oxygen pressure $65 \mathrm{~mm} \mathrm{Hg}(8 \cdot 7 \mathrm{kPa})$, carbon dioxide pressure $48 \mathrm{~mm} \mathrm{Hg}(6.4 \mathrm{kPa})$, base excess $-18 \mathrm{mmol}(\mathrm{mEq}) / \mathrm{l})$ was corrected with sodium bicarbonate. Urea, electrolyte, and blood glucose concentrations were within normal limits. Blood was taken for poisons analysis. Over the next hour blood pressure rose to $130 / 80 \mathrm{~mm} \mathrm{Hg}$ and electrocardiography showed a sinus tachycardia of 105 beats $/ \mathrm{min}$. Urinary output was satisfactory and her temperature stable at $36.9^{\circ} \mathrm{C}$. Despite adequate haemodynamic control she remained comatose and continued to have further convulsions. Respiratory depression ensued and she required ventilation. Her condition deteriorated further with the onset of bradyarrhythmias unresponsive to atropine and isoprenaline. Cardiac arrest occurred and she died six hours after admission to hospital.

At necropsy the only finding of note was moderate pulmonary oedema. The results of the poisons analysis confirmed high concentrations of indoramin and ethanol $(6.44$ and $2250 \mathrm{mg} / 1$ respectively) but only therapeutic concentrations of temazepam and oxazepam $(0.16$ and $0.03 \mathrm{mg} / \mathrm{l})$; paracetamol, barbiturate, and salicylate were not detected. Plasma indoramin concentration after an oral dose of $100 \mathrm{mg}$ is $0.03-0.12 \mathrm{mg} / \mathrm{l}$; thus the concentration in this patient was approximately 50-200 times greater than therapeutic values.

\section{Comment}

Indoramin is being increasingly used in the treatment of essential hypertension, yet little is known about its toxicology in man. It is well absorbed by mouth, and peak plasma concentrations occur one to two hours after ingestion. ${ }^{1}$ It is thought to act by selective antagonism of postsynaptic alpha ${ }_{1}$-adrenergic receptors that normally mediate vasoconstriction. ${ }^{2}$

This is the first reported case of self-poisoning with indoramin. The main clinical features were deep sedation, respiratory depression, hypotension, and convulsions. Although the hypotension was satisfactorily controlled, the effects on the central nervous system were resistant to treatment and proved fatal. There are no previous reports of indoramin-induced convulsions in man, but fits have been observed in animals given high doses ( $\mathrm{P} K$ Marrott (Wyeth Laboratories) personal communication). The serum ethanol concentration, though raised, is unlikely to have accounted for the severity of the clinical state.

Treatment of indoramin poisoning should include prompt gastric lavage, circulatory support to control hypotension, and diazepam for convulsions. Although no specific antidote exists, infusion of alphaadrenoceptor agonists, such as noradrenaline or metaraminol, may prove beneficial.

Sedation $^{3}$ and depression ${ }^{4}$ are recognised central side effects of indoramin. This case shows that indoramin taken in overdosage is fatal. It would therefore seem wise to exercise caution before prescribing indoramin to patients with a history of depressive illness.

I thank Dr P K Marrott of Wyeth Laboratories and Dr G N Volans of the Poisons Unit, New Cross Hospital, London for help with the poisons analysis.

${ }^{1}$ Draffan GH, Lewis PJ, Firmin JL, et al. Pharmacokinetics of indoramin in man. Br f Clin Pharmacol 1976;3:489-95.

${ }^{2}$ Algate DR, Waterfall JF. Action of indoramin on pre and post synaptic alpha adrenoceptors in pithed rats. F Pharm Pharmacol 1978;30:651-2.

${ }^{3}$ Johnson ES. Indoramin in essential hypertension: a survey of the patient records from long term clinical trials. Br $\mathcal{F}$ Clin Pharmacol 1981;12: $131 \mathrm{~S}-7 \mathrm{~S}$.

4 Fitzgerald MVJ. A long term open evaluation of indoramin in hypertension. Br f Clin Pharmacol 1981;12:117S-23S.

(Accepted 15 fuly 1982)

Southern General Hospital, Glasgow G51 4TF

ROBERT HUNTER, BSC, MB, medical senior house officer

\section{Cheap and effective method of weighing bed-bound patients}

Recording a patient's weight is easy in ambulant or semi-ambulant patients, but seriously ill patients pose a greater problem. Most of the existing devices capable of lifting and weighing a normal hospital bed are bulky, difficult to manoeuvre, and expensive. We have developed a simple, inexpensive, and easily transportable device for weighing bed-bound patients. Most of the patients were receiving nutritional support, and consequently we wished to chart their weight throughout their treatment.

\section{Method}

The technique requires use of four sets of bathroom scales and one stretcher. One set of scales is placed under each leg of the bed on which the patient is lying, the scales having been previously "zeroed." (To maintain the bed leg in a constant position on the scales a furniture leg "load spreader" is glued to the centre of the scales.) A reading is then taken from each of the scales and the four values summed. This gives a value for bed plus patient. A variable-height trolley with detachable canvas portion (Institutional Industries, Cincinnati, Ohio) is then used to raise the patient clear of the bed: the canvas portion is placed under the patient, the tubular frame manoeuvred into position so that the canvas can be reattached to the frame, and the trolley then wound up so that the patient is lifted clear of the bed. Drainage bags, etc, may be left in situ as the patient need be lifted only a few inches. Consequently only the patient, and not the apparatus and drained fluid, is weighed (figure). Once the patient has been raised clear of the bed the four scales are read again and the readings summed. This total represents the weight of the bed alone. By subtracting the bed alone value from the bed plus patient value the patient's weight may be calculated.

To test the accuracy of our method we conducted a trial with 20 ambulant volunteers. Five different hospital beds were used. For each volunteer we derived two readings, one for bed alone and one for bed plus patient, and then calculated the volunteer's weight using our simple equation. The scales were removed and zeroed if required. The volunteer was then weighed on each of the four scales. The readings were taken by a second observer, who was unaware of the volunteer's calculated weight. The calculated average reading represented the volunteer's actual weight.

The calculated weight was less than the actual weight in 15 of the 20 subjects and greater in four; in one case the two weights were identical. The range of error was -1.6 to $+0.9 \mathrm{~kg}$, with a mean of $0.36 \mathrm{~kg}$; this error was not significant (Student's $t$ test). 